\title{
EVALUATION OF HISTOLOGICAL FINDINGS OF AIRWAYS OF RATS EXPOSED TO HIGHLY POLLUTED INDOOR AIR IN OFFICES
}

\author{
Žanna Martinsone $e^{1, \#}$, Māra Pilmane ${ }^{2}$, Georgijs Moisejevs $^{3}$, Dagmāra Sprūdža ${ }^{1}$, \\ and Mārìte Ārija Baḳe ${ }^{1}$ \\ ${ }^{1}$ Institute of Occupational Safety and Environmental Health, Rīga Stradinš̌ University, Dzirciema iela 16, Rīga, LV-1007, LATVIA \\ Zanna.Martinsone@rsu.Iv; Dagmara.Sprudza@rsu.Iv; Marite.Bake@ rsu.Iv \\ ${ }^{2}$ Institute of Anatomy and Anthropology, Rīga Stradinš University, Dzirciema iela 16, Rīga, LV-1007, LATVIA \\ Mara.Pilmane@rsu.Iv \\ ${ }^{3}$ Laboratory of Biochemistry, Rīga Stradinš University, Dzirciema iela 16, Rīga, LV-1007, LATVIA \\ georgijs.moisejevs@gmail.com \\ \# Corresponding author
}

Contributed by Māra Pilmane

\begin{abstract}
Humans are exposed to chemicals and PM (particulate matter), including ultrafine particles (nanoparticles), mainly through inhalation. This creates a risk to their health. Another effect to exposure is expression of cytokines and their role in lung inflammation and morphpathogenesis. We conducted a pilot project based on testing of realistic exposure scenarios by describing morphological changes of the respiratory tract in Wistar rats (male) during a 30-day exposure in office where there was high intensity of printing activities. Tracheal tissue of experimental animals had increasing concentrations of inflammatory interleukin IL-1 and decreasing concentrations of IL-6 and TNF- $\alpha$. The lungs of the experimental animals tended to show focal infiltration of inflammatory cells, vascular plethora, focal and/or diffuse localisation of lymphatic nodules, and also vascular sclerosis and focal emphysema. The results suggested potential dangerous and adverse effect of poor indoor air quality (particles, including nanoparticles, and chemical compounds) on respiratory tract tissue of rats.
\end{abstract}

Key words: indoor air quality, rats' trachea tissue, rats' lung tissue, IL6, IL1, TNF- $\alpha$.

There is growing recognition that increased levels of chemical pollutants and particles (particulate matter, PM) may cause risk to human health. Much research is presently focused on impact of particles (including nanoparticles with size less than $100 \mathrm{~nm}$ or $0.1 \mu \mathrm{m})$. Uptake of PM and chemicals in the air occurs mainly through their inhalation and contact with the surface of the nose, throat, laryngeal, tracheal, bronchial, and lung structures. Depending on dispersity, particles have different degrees of toxicity to the respiratory tract. For example, particles with aerodynamic diameter of more than $10 \mu \mathrm{m}$ are filtered in the nose, pharynx and larynx, particles with size of 5-8 $\mu \mathrm{m}$ are usually deposited in the tracheobronchial tree, and 1-5 $\mu \mathrm{m}$ or smaller particles - in the respiratory bronchioles and alveoli. Furthermore, ultrafine particles (UFP) or nanoparticles $(<0.1 \mu \mathrm{m})$ are capable of penetrating into epithelial cells and entering the bloodstream from the lungs. The human body defence system (mucus secretion, protective reflexes, mucin, defensin, immunoglobulin A, local macrophage sys- tem, epithelium barrier, mucociliary mechanism, and surfactants) works to protect the organism from the various effects of inhaled substances and air pollution in general (Gilmour et al., 2004).

Experimental studies on rodents and cell cultures have shown that the toxicity of ultrafine or nanoparticles is greater than larger particles with the same mass and similar chemical composition (Barlow et al., 2005; Nel et al., 2006; Mossman et al., 2007; Araujo et al., 2008). In addition to particle surface area also other particle characteristics (solubility, shape, and surface chemistry etc.) may influence toxicity (Anonymous, 2006; Donaldson et al., 2006).

Various types of office equipment (printing and copy machines) are widely used, and therefore some studies have been focused on the monitoring of particle and chemical substances in large open offices where increased loads of particle in indoor air have been promoted by use of different printers (Congrong et al., 2007). 
Inhalation of UFP impairs systemic vascular function and reduces bioavailability of nitrogen monoxide (NO), thus creating potential health risk linked to particle exposure and adverse cardiovascular effects (Shah et al., 2008).

Although the potential health risk following exposure to a substance is generally associated with the magnitude and duration of the exposure, the persistence of the material in the body, the inherent toxicity of the material, and the susceptibility or health status also play roles (Anonymous, 2006; Donaldson et al., 2006)

There is much controversial scientific information about effects of exposure to particles on cells (for example, macrophages etc.) and expression of cytokines, which play a role in development of lung inflammation and morphopathogenesis in lungs (Määttä et al., 2006). High concentrations of particles and chemical substances in the air may cause different illnesses of the respiratory tract (chronic rhino sinusitis, asthma, obstructive bronchiolitis, and lung or pleura cancer, etc.).

There is a lack of information on the potential health effects of high levels of particle exposure in combination with high concentrations of compounds in indoor air. Knowledge about interaction of these factors with the body's biological systems is essential for prediction of health effects.

The aim of the pilot project was to test realistic exposure scenarios by describing morphological changes in the respiratory tract of Wistar rats during 30-day exposure in an office with high intensity of printing in comparison with an office without printing activities.

This pilot study was carried out in consideration of Animal Welfare and good laboratory practice principles. Ten Wistar white rats (five in control and five in experimental group) were used in the experiment. The study received authorisation from the Food and Veterinary Service Ethics Commission of Latvia (No. 19/11.03.2010).

Rats of the experimental group were exposed to polluted office indoor air, which was simulated by a high printing load (3000-5000 pages per day) and lack of a ventilation system. The duration of realistic exposure scenarios was $8 \mathrm{~h}$ during five working days (together 30 working days), the cage with rats was situated near printing/copy machines; during weekends, the animals were placed in a room without printing activities in the same building, which had a low background level of indoor air pollution. Animals of the control group were housed in the same room. The following parameters of indoor air quality were determined: particle surface area (alveolar and tracheobronhial fraction) by TSI Inc. (USA) company instrumentation "AeroTrak 9000" (particle size range: 10-1000 nm), volatile organic compounds were determined by gas chromatography (Varian 3800, Agilent, USA), oxides and ozone by spectrophotometer (Varian Cary 50, Agilent, USA), and formaldehydes by high performance liquid chromatography HPLC (Waters Alliance" W2690/5, Waters Corp., USA). The indoor air quality in the polluted office (experimental rats) and in the control office (low background level concentration for rats of the control group) was the following: average alveolar fraction particle surface area $-42.4 \mathrm{\mu m}^{2} / \mathrm{cm}^{3}$ and $12.5 \mu \mathrm{m}^{2} /$, average traheobronhial fraction particle surface area - 12.6 $\mu^{2} / \mathrm{cm}^{3}$ and $9.6 \mu \mathrm{m}^{2} / \mathrm{cm}^{3}$, average volatile organic compounds concentration $-0.9 \mathrm{mg} / \mathrm{m}^{3}$ and $0.1 \mathrm{mg} / \mathrm{m}^{3}$, formaldehyde $-0.5 \mathrm{mg} / \mathrm{m}^{3}$ and $0.05 \mathrm{mg} / \mathrm{m}^{3}$, ozone $-1.2 \mathrm{mg} / \mathrm{m}^{3}$ and $0.2 \mathrm{mg} / \mathrm{m}^{3}, \mathrm{NO}_{\mathrm{x}}-0.12 \mathrm{mg} / \mathrm{m}^{3}$ and $0.04 \mathrm{mg} / \mathrm{m}^{3}$, and $\mathrm{SO}_{2}-0.24 \mathrm{mg} / \mathrm{m}^{3^{\mathrm{x}}}$ and $0.08 \mathrm{mg} / \mathrm{m}^{3}$. The differences in concentrations between the exposure scenario and control varied from two times (traheobronhial fraction) to ten times (formaldehyde).

After the exposure and sampling of blood analyses, the experimental animals were euthanised and histological material of lungs and trachea were taken in laboratory conditions.

Tissues were fixed in a mixture (2\% formaldehyde, $0.2 \%$ picric acid, 0.1 M phosphate buffer solution ( $\mathrm{pH} 7.2)$ ), and then washed for $12 \mathrm{~h}$ in thyroid buffer solution that contained 10\% sucrose. Then, tissue was laid in paraffin and cut into $5 \mathrm{~mm}$ thick sections by a microtome. Haematoxylin and eosin (h/e) staining was used for tissue observations. The following immunohistochemical antibodies (IMH; Hsu et al., 1981) were used: IL-1 $\alpha$ (mice, working dilution 1:100, Santa Cruz Biotechnology, Inc.), IL-6 (mice, 1:50, Santa Cruz Biotechnology, Inc.), TNF- $\alpha$ (rabbit, 1:100, Abcam). TUNNEL was used to determine of cell apoptosis (No. 11684817910, Roche Diagnostics, Germany) (Negoescu et al., 1998).

The semiquantitative counting method was used for the quantification of structural change (" 0 " - negative reaction, " $0 /+$ " - rare highlighted structure till " ++++ +" - very much highlighted structure in the visual field (Pilmane, 1997).

Statistical analysis was performed with the non-parametric Mann-Whitney test for two independent groups, using SPSS version 17.0. Results were considered statistically significant at level $-p<0.05$.

Significant differences intensity of inflammatory infiltration, oedema of tissue, hyperplasia of tracheal epithelial basal cells, amount of secondary nodules and degeneration of hyaline cartilage between control and experimental animals groups were not found. However, hyperplasia of mucosal basal cell and degeneration of hyaline cartilage were observed only in animals of the experimental group $(p>0.05)$. In contrast, lymphoid nodules were observed only in control animals $(p<0.05)$.

The analyses of lung tissue of experimental animals showed non-significant increased focal infiltration of inflammatory cells, vascular plethora, focal and/or diffuse location of lymphatic nodules $(p>0.05)$ and significant increase $(p<$ 0.05 ) of vascular sclerosis (Fig. 1).

In tracheal tissue of experimental animals there were nonsignificant higher levels of inflammatory cytokines IL-1 


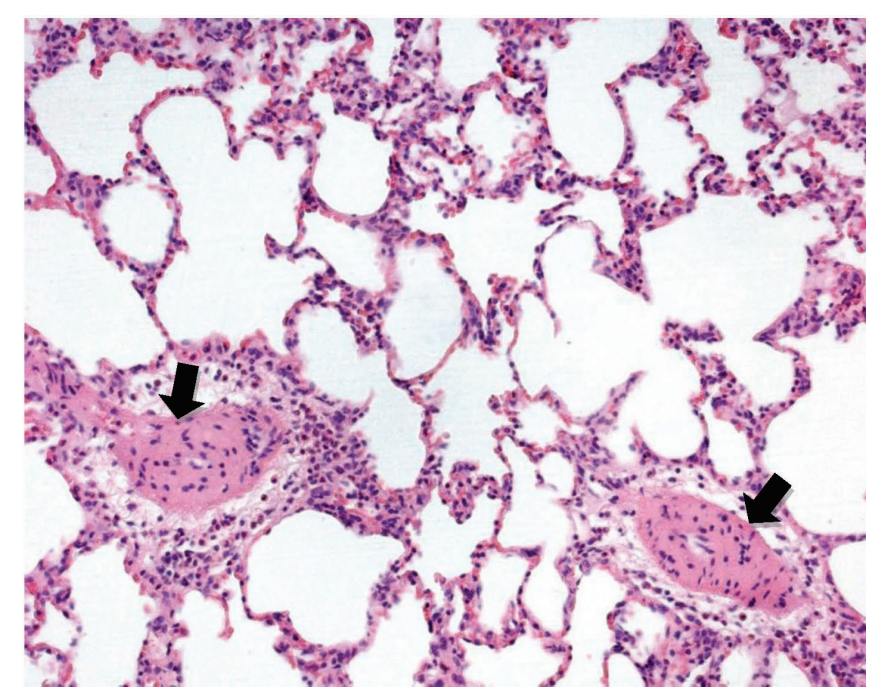

Fig. 1. Sclerosis with luminal obliteration (see black arrows) of the blood vesels of an experimental rat. X200. Hematoxylin and eosin.

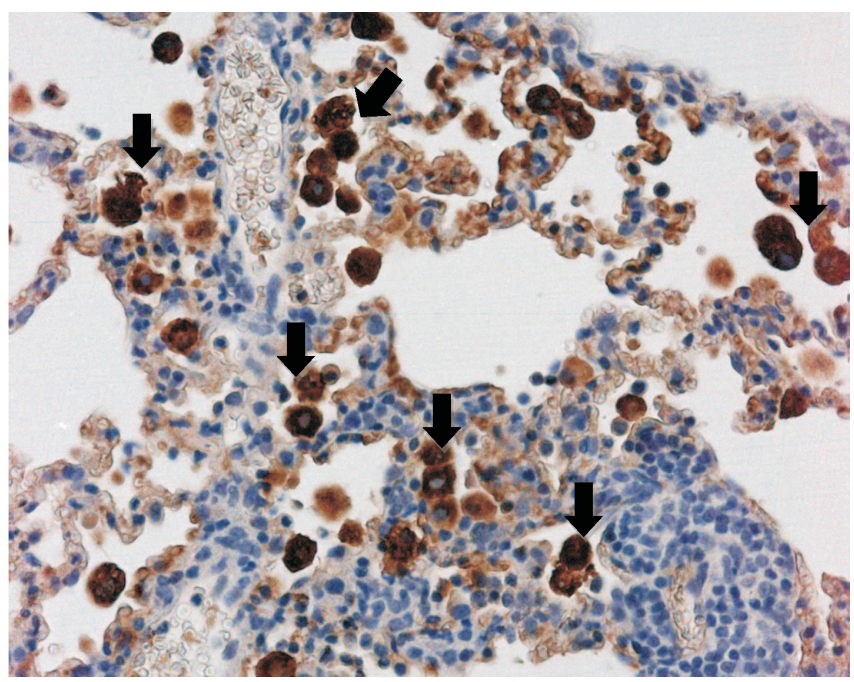

Fig. 2. Conglomerates of IL-1 expressing alveolar macrophages (see black arrows) in experimental rat lung. X400. IHC IL-1.

$(p>0.05)$ and lower levels of IL-6 $(p>0.05)$ and TNF $\alpha(p$ $>0.05)$. Some infiltration of inflammatory cell $(p>0.05)$ and emphysema $(p>0.05)$ was observed among experimental animals (see Fig. 2). Increase of IL-1 level was observed in cells of lung tissue of experimental animals. Counts of IL-6- and TNF- $\alpha$-containing cells differed between groups. Apoptotic cell density was higher in the experimental animals $(p>0.05)$. Expression of lung tissue cytokines IL-1 and IL- 6 was non-significantly higher in experimental group animals.

High levels of indoor air pollution (PM and chemicals) might explain hyperplasia of the basal cells in mucosa and inflammatory cell infiltration among tracheal tissues of the experimental group animals, as a study on UFP by Kipen and Laskin (2005) showed dose-dependent accumulation of inflammatory cells (neutrophils, lymphocytes and macrophages) in the respiratory system. Signs of inflammation (inflammatory cell infiltration and hyperemia) were also observed in lungs of the experimental animals, which might be assumed as the cause of blood vessel sclerosis and emphy- sematous foci. Some histological studies on lungs of mice after exposure to the PM showed granulomas and difuse interstitial fibrosis (Kipen and Laskin, 2005), as well as type II alveolocyte injury (Reinwick et al., 2004; Chen et al., 2006), emphysematous changes and significant increase in alveolar macrophage accumulation (Chen et al., 2006).

A number of recent studies indicated that the inflammatory response depends on the surface area of particles deposited in the proximal alveolar region of the lungs. Particle surface area is a better metric than mass for relating the particle dose to the inflammatory reaction. When the inhaled dose reaches a critical level, an inflammatory response occurs (Nel et al., 2006).

Decrease of lymphatic foliculi in both trachea and lung tissue of experimental animals compared to the control group is thought to be due to decompensation of the immune system.

Expression of IL-1 had a tendency to increase, but expression of IL- 6 and TNF- $\alpha$ tended to decrease in the trachea, but variable in the lungs, showing intensive expression in loci of the inflammatory infiltrates, perhaps due to local reactivity. Studies on mice revealed dose-dependent increase of IL-1 and TNF- $\alpha$ levels in the bronchoalveolar lavage and in the macrophage culture after exposure to PM (Kipen and Laskin, 2005). Anpther triple cell model study showed significant increase in TNF- $\alpha$ production only in interaction with fine particles (Rothen-Rutishauser et al., 2007). All of the reported observations can be explained by decompensation of the immune response as a response to polluted indoor air exposure (mixed exposure of particles, chemicals etc. agents).

The main conclusions of this pilot study are that poor indoor air quality in the office due to high intensity amount of printing/coping processes might have caused tissue damage of rat trachea and lungs among the experimental group of animals, including adverse effects of mixtures of pollutants on rat trachea and lung tissues.

Further research is needed to model realistic scenarios of exposure, taking into account real cross-combinations of various factors and environmental conditions of indoor air pollutants. Studies should concentrate on the immunological pathways in the future.

\section{ACKNOWLEDGEMENTS}

Project No. EEZ09AP-22 “Determination of indoor air pollution caused by offices equipment and estimation of possible impact on organism". The authors thank Ivars Vanadziňš (Director, Agency of Rīga Stradiňš University, Institute of Occupational Safety and Environmental Health) for scientific support.

\section{REFERENCES}

Anonymous (2006). Approaches to safe nanotechnology: An information exchange with NIOSH. National Institute for Occupational Safety and 
Health, Centers for Disease Control and Prevention. Available at: http://www.cdc.gov/niosh/topics/nanotech/pdfs/Approaches_to_Safe_Nanotechnology.pdf (accessed 30 September 2016).

Araujo, J. A., Barajas, B., Kleinman, M., Wang, X., Bennet, B. J., Gong, K. W., Navab, M., Harkema, J., Sioutas, C., Lusis, A. J., Nel, A. E. (2008). Ambient particulate pollutants in the ultrafine range promote early atherosclerosis and systemic oxidative stress. Circ. Res., 102, 589-596.

Barlow, P. G., Clouter, B. A., Donaldson, K., McCollum, J., Stone, V. (2005). Carbon black nanoparticles induce type II epithelial cells to release chemotoxins for alveolar macrophages. Particle Fibre Toxicol., 2 (1), 11.

Chen, H. W., Su, S. F., Chien, C. T., Lin, W. H., Yu, S. L., Chou, C. C., Chen, J. W., Yang, P. C. (2006). Titanium dioxide nanoparticles induce emphysema-like lung injury in mice. J. Feder. Amer. Soc. Exp. Biol., 20, E1732-E1741

Congrong, H. E., Morawska, L., Taplin, L. (2007). Particle emission characteristics of office printers. Environ. Sci. Technol., 41, 6039-6045.

Donaldson, K., Aitken, R., Tran, L., Stone, V., Duffin, R., Forrest, G., Alexander, A. (2006). Carbon nanotubes: A review of their properties in relation to pulmonary toxicology and workplace safety. Tox. Sci., 92 (1), 5-22.

Gilmour, P. S., Ziesenis, A., Morrison, E. R., Vickers, M. A., Drost, E. M., Ford, I., Karg, E., Mossa, C., Schroeppel, A., Ferron, G. A., Heyder, J., Greaves, M., MacNee, W., Donaldson, K. (2004). Pulmonary and systemic effects of short-term inhalation exposure to ultrafine carbon black particles. Toxicol. Appl. Pharmacol., 195, 35-44.

Hsu, S. M., Raine, L., Fanger, H. (1981). The use of antiavidin antibody and avidin-biotin-peroxidase complex in immunoperoxidase technics. Amer. J. Clin. Pathol., 75, 816-821.
Kipen, H. M., Laskin, D. L. (2005). Smaller is no always better: Nanotechnology yields nanotoxicology. Amer. J. Physiol.: Lung Cell. Mol. Physiol., 289, 296-297.

Määttä, J., Luukkonen, R., Husgafvel-Pursiainen, K., Alenius, H., Savolainen, K. (2006). Comparison of hardwood and softwood dust-induced expression of cytokines and chemokines in mouse macrophage RAW 264.7 cells. Toxicology, 218 (1); 13-21.

Mossman, B. T., Borm, P. J., Castranova, V., Cost, D. L., Donaldson, K., Kleeberger, R. (2007). Mechanisms of action of inhaled fibers, particles and nanoparticles in lung and cardiovascular disease. Particle Fibre Toxicol., 4, 4.

Negoescu, A., Guillermet, C., Lorimier, P., Brambilla, E., Labat-Moleur, F. (1998). Importance of DNA fragmentation in apoptosis with regard to TUNEL specificity. Biomed. Pharmacother., 52, 252-258.

Nel, A., Xia, T., Maedler, L., Li, N. (2006). Toxic potentials of materials at the nanolevel. Science, 311, 622-627.

Renwick, L. C., Brown, D., Clouter, A., Donaldson, K. (2004). Increased inflammation and altered macrophage chemotactic responses caused by two ultrafine particle types. Occup. Environ. Med., 61, 442-447.

Rothen-Rutishauser, B., Mühlfeld, C., Blank, F., Musso, C., Gehr, P. (2007). Translocation of particles and inflammatory responses after exposure to fine particles and nanoparticles in an epithelial airway model. Particle Fibre Toxicol., 4, 9.

Shah, A. P., Pietropaoli, A. P., Frasier, L. M., Speer, D. M., Chalupa, D. C., Delehanty, J. M., Huang, L. S., Utell, M. J., Frampton, M. W. (2008). Effect of inhaled carbon ultrafine particles on reactive hyperemia in healthy human subjects. Environ. Health Perspect., 116 (3), 375-380.

Received 21 September 2016

\section{ELPCEL,U HISTOLOĢISKO IZMAIN̦U NOVĒRTĒJUMS ŽURKĀM, KURAS PAKL,AUTAS AUGSTAM BIROJA TELPU PIESĀRNOJUUMAM}

Cilvēki ir pakḷauti dažādu k̦īmisko vielu un cieto dalịnu (particulate matter), ieskaitot smalko daḷiņu (mazāku par 0,1 $\mu$ m) ietekmei, galvenokārt ieelpojot, tādējādi radot risku viṇu veselībai. Pētījums veikts reālos apstākḷos — izpētītas elpceḷu morfologíiskās izmainas Wistar žurkām (tēviṇiem), kuras 30 dienas atradās biroja telpās ar paaugstinātu piesārnojumu. Telpā tika veikti intensīvi printēšanas/kopēšanas darbi. Pētījuma rezultātā atrastas atškirīgas izmaiņas kontroles un eksperimenta dzīvnieku trahejas audos — palielināts interleikīna IL-1 un novērota IL-6 un TNF- $\alpha$ samazināšanās tendence. Eksperimenta dzīvnieku plaušu testēšanas rezultāti parādīja, ka novērojamas šādas galvenās izmaiṇas: iekaisuma šūnu lokāla infiltrācija, asinsvadu pārpilnība, limfātisko mezgliṇu difūza lokalizācija, asinsvadu skleroze un centrāla emfizēma. Iekštelpu gaisa kvalitātes mērījumi uzrādīja biroja telpas augstu piesārņojumu ar kịmiskiem savienojumiem un dalịn̄ām, t.sk. nanodalịnām, kas varētu būt par cēloni eksperimenta dzīvnieku trahejas un plaušu audu patoloğiskām izmainām. 